DOI 10.31558/2519-2949.2018.1.13

УДК 329.8(477)

Поліщук І. О., Національний юридичний університет імені Ярослава Мудрого

\title{
МОДЕРНІЗАЦІЯ ПАРТІЙНОЇ СИСТЕМИ ЯК ЗАСІБ ДЕМОКРАТИЗАЦІЇ ПОЛІТИЧНОГО РЕЖИМУ УКРАЇНИ
}

\begin{abstract}
Розглянуто змістовну суть та сучасні тенденції розвитку інституту політичних партій в Україні. Мета даної статті полягає у тому, щоби розглянути сучасне поняття політичної партії та запропонувати механізми модернізащії партійної системи України задля забезпечення демократизачї̈ політичного режиму, що утворився у нашій країні. Автор стверджує, що політичні партії за своїм покликанням апріорі виступають як провідний суб'єкт демократизації політичної системи транзитивного суспільства. Головна проблема Украӥни полягає в тому, щчо клановоолігархічний (неопатрімоніальний) політичний режим та бюрократично-корпоративна, тіньова економіка не сприяють створенню дієздатних політичних партій, усередині яких ведеться чесна та відкрита конкуренція, а сприяє створенню політичних компаній за комериійними інтересами. Політичні партії України не виконують своє основне призначення, не забезпечують політичну освіту мас та не надають иілеспрямованого й організованого характеру діям громадян для захисту власних інтересів. Основна функиія украӥнських партій - це маніпулювання масовою свідомістю вибориів під час проведення відповідних кампаній. Слабкість українських політичних партій, їхня організаиійна та ідейна аморфність відкривають перед командами політичних технологів доволі широку перспективу доведення їх до необхідної ,,електоральної кондииї”. Основні політичні партії представляють з себе своєрідні напівфабрикати для майбутньої виборчої кампанії.

Для сучасної України є актуальною проблема інтенсифікаиії партійного будівництва та кристалізації партійної системи України в бік їі позбавлення від баласту віртуальних та недієздатних структур та лідерів, які не беруть реальної участі в політиці. 3 іншого боку, є багато партійних структур та брендів, які якщо й беруть участь у політичному процесі, то не мають попиту на електоральному ринку.

Сформульовані рекомендачії щодо впровадження механізмів модернізаиії украӥнської партійної системи.
\end{abstract}

Ключові слова: політична партія, Україна, модернізачія, демократизація, політичний режим.

Актуальність проблеми модернізації української партійної системи визначається необхідністю реальної демократизації політичного режиму нашої країни. Політичні партії з політичних надбудов економічних холдингів покликані перетворитися на реальних суб'єктів політичного процесу. Виборча кампанія в органи місцевого самоврядування, яка відбулася у жовтні 2015 року, відзначалася тією обставиною, що проходила за новими „правилами гри”. Як відомо, у минулих виборчих кампаніях 1998 та 2002 років використовувалася змішана система виборів, за якої 50\% депутатів обиралися у мажоритарних округах та $50 \%$ депутатів обиралися за пропорційним принципом по партійних списках. У березні 2004 року народні депутати ухвалили новий виборчий закон, за яким впроваджується у виборах до Верховної Ради України та органи місцевого самоврядування виключно пропорційна виборча система з закритими списками. Право на участь в розподіленні депутатських мандатів отримали лише кандидати, які включені у виборчий список політичних партій або виборчих блоків. Згідно нових правил виборів, кандидатів у депутати висувала тільки політична партія або виборчий блок політичних партій, які були зареєстровані у встановленому законом порядку не пізніше як за один рік до проведення виборів. При цьому закон не забороняє включати до виборчих списків безпартійних громадян. Позаяк це означає, що політичні партії перетворюються на гравців-монополістів, єдиних дієвих суб'єктів в електоральному процесі України та отримують потужний імпульс для свого розвитку.

Актуалізується проблема інтенсифікації партійного будівництва та кристалізації партійної системи України в бік ії позбавлення від баласту віртуальних структур та лідерів, які не беруть реальної участі в політиці, а якщо й беруть участь, то не мають попиту на електоральному ринку. Данні неординарні процеси вимагають від вітчизняної політичної науки більшу увагу приділяти

(C) Поліщук I. O., 2018 
вивченню політичних партій як суб'єктів електорального процесу в Україні, прогнозуванню процесу розвитку нашої партійної системи.

Аналізуючи розробленість подібної дослідницької проблематики в світовій та українській партології, слід зазначити, що відомі закордонні фахівці Дж.Сарторі, М.Дюверже, А.Лейпхарт, Ш.Авінері, Г.Алмонд, С.Вятр, С.Ліпсет, С.Роккан, С.Нойман при характеристиці сучасного стану і перспектив розвитку партій як політичних інститутів вказують на безпосередній зв’язок та взаємний вплив між партійною та виборчою системами. Особлива увага вітчизняних партологів М.Примуша, Н.Гончарука, А.Пахарєва, І.Кресіної, О.Сржова, В.Литвина, Г.Малкіна, Ю.Шведи концентрується на проблемі впливу електорального процесу на становлення партійної системи в Україні.

Мета даної статті полягає у тому, щоби розглянути сучасне поняття політичної партії та запропонувати механізми модернізації партійної системи України задля забезпечення демократизації політичного режиму, що утворився у нашій країні.

Розгляд суб'єктності партій в електоральному процесі розпочинається авторитетними політологами Дж. Ла Поламбарою, Ж.Шарло, О.Кіршеймером, коли вони висловили незгоду з бінарною класифікацією М. Дюверже, стверджуючи, що наприкінці XX в. не можна дорівнювати кадрову партію до архаїчної моделі, а масову - до прогресивної [3, p. 123] Дж. Ла Паломбара й М.Вейнер виділили новий тип партії - електоральні партії, умовно назвавши їх „партії хапай усіх”, що згодом була позначена терміном „партії виборців” (Ж.Шарло). Цей тип партії характеризується виборчим прагматизмом, але не створює мережі організованих прихильників на кшталт кадрових партій, а з іншого має централізовану масову організацію, не вимагаючи від своїх членів постійної участі у партійному житті. Такими є партії центристського спрямування. „Партія виборців” орієнтована на мобілізацію можливо більшої частини електорату незалежно від соціальної, професійної чи етнічної належності (Демократично-християнська партія Італії, чия мета сьогодні має мало спільного із соціальною доктриною церкви; Соціал-демократична партія Німеччини, що дистанціонується від марксизму; подібну тягу до деідеологізації демонструє зараз і Соціалістична партія Франції).

У західній політології в аналізі політичних партій досить впливовою є і модель норвезького політолога С.Роккана [5, с.37]. С.Роккан побудував партійно-політичну модель Свропи на основі концепції ідейно-політичних розламів - кліважів (фр. clivage, англ. cleavage - розшаровування, поділ), що визначають, зокрема, розмір і якість національних партійних систем. С. Роккан запропонував чотири „критичні точки” як головні організуючі віхи на шляху, що довелося пройти всім державам і політичним утворенням Західної Свропи. Це Реформація, національна революція (вплив Французької революції), промислова революція й „комуністична” революція. Його в першу чергу цікавили зрушення в структурі владних союзів усередині правлячих політичних сил і серед еліт. Загальною рисою цих схем була увага до відносин центр/периферія: у процесі націє творення між національним центром, що модернізується, і периферією мають місце численні економічні, юридичні, культурні й т.п. протиріччя. Кліважі супроводжуються виникненням стійких комплексів (політичних) переваг, навколо яких формувалися європейські політичні партії. Після виникнення базових електоральних структур (інститутів, у тому числі правил голосування) відбувається ,затвердіння” кліважів і електоральних структур (інститутів), їхня стабілізація.

Як відомо, політичні партії $є$ невід'ємним елементом політичної системи сучасних демократичних режимів. Вони виступають зв'язуючою ланкою між державою та громадянським суспільством. У класичному розумінні політична партія - цее організація, щзо об'єднує на добровільній основі найактивніших представників тих чи інших класів, соціальних верств та груn. Основним призначенням партії $\epsilon$ політична освіта мас та надання цілеспрямованого й організованого характеру їх діям для захисту власних інтересів. Як свідчить історична практика, політичні партії в усіх країнах створювалися як інструмент боротьби за владу та перенесення інтересів різних ідейно-політичних течій у реальну політику держави.

Модерне уявлення про політичні партії відображає наступне визначення: „Політичні партії - це громадські утворення, що переслідують мету вибороти владу в державі, утримати іiі, ефективно використовувати, реалізуючи політичну волю громадян.” [4, с. 11-12 ] Крім Конституції України статус політичних партій в нашій країні закріплено в Законі України “Про об'єднання громадян”(від 16 липня 1992 р.), Законі України „Про політичні партії”( від 25 квітня 2001 р.), „Положенні про порядок легалізації об'єднань громадян”, затвердженого Кабінетом Міністрів України 26 лютого 1993 р. та у виборчому законодавстві.

Згідно зі ст. 2 Закону України „Про політичні партії України” політична партія - це зареєстроване згідно 3 законом добровільне об'єднання громадян-прихильників певної 
загальнонаціональної програми суспільного розвитку, що має своєю метою сприяння формуванню і вираженню політичної волі громадян, бере участь у виборах та інших політичних заходах. [2, с.28].

У структурно-функціональному плані сучасна партія це система таких ознак: партія = ідеологія + організаційна структура + методи і засоби діяльності + соціальна база та електорат + фінасова база + політичні лідери. [1, с. 27].

Політичні партії у сучасному розумінні остаточно сформувалися одночасно 3 еволюцією виборчого права в напрямку утвердження прямих, рівних, загальних виборів за умови таємного голосування.

Місце та роль політичних партій в сучасній політичній системі демократичного суспільства розкривають їх функції: представництво інтересів громадян; узгодження та узагальнення цих інтересів; політична соціалізація; комунікативна; політичне рекрутування; розробка „правил політичної гри"(законів) для суспільства; ідейно-політична боротьба; владна (для правлячих партій); критика влади (для опозиційних партій); кадрова - підготовка та висунення кадрів для держапарату; розробка ідеології та політичної доктрини; активізація та інтеграція великих соціальних груп; участь у формуванні та вдосконаленні політичних систем, і нарешті електоральна.

Політична та соціально-економічна система стосунків, що сформувалася натепер в Україні: кланово-олігархічний (неопатрімоніальний) політичний режим та бюрократично-корпоративна, багато в чому тіньова економіка, на жаль, не сприяють створенню дієздатних політичних партій, усередині яких ведеться чесна та відкрита конкуренція, а сприяє створенню політичних компаній за комерційними інтересами. Фактично провідні партії в Україні представляють 3 себе політичні холдинги найбільш потужних фінансово-промислових угруповань. Українські партії відповідним чином фінансуються та виконують функцію не представництва та захисту інтересів певних соціальних груп, а обслуговують інтереси своїх хазяїв, які далеко небезкорисно спонсорують політичні проекти, намагаючись зробити їх об’єднаннями своїх креатур з метою лобіювання бізнес інтересів. Слабкість українських політичних партій, їхня організаційна та ідейна аморфність відкривають перед командами політичних технологів доволі широку перспективу доведення їх до необхідної „електоральної кондиції”. Основні політичні партії, включаючи й нові "партії влади" $з$ точки зору деяких PR-технологів в теперішньому вигляді представляють 3 себе своєрідні напівфабрикати для майбутньої виборчої кампанії. Відомий російський політтехнолог Г.Павловський висловив думку, яку цілком можна застосувати й щодо України: "Поміж виборами наші партії $\epsilon$ „сировиною,, для майбутніх виборчих проектів". Тобто партії на пострадянському просторі - це недороблений товар, а вибори - це „конкурси електоральних проектів”.

Зрозуміло, що трансформація подібного стану речей неможлива без проведення інституційних та політико-правових зрушень у бік демократизації процесу утворення та діяльності політичних партій в Україні.

Політичні партії за своїм покликанням апріорі виступають як провідний суб'єкт демократизації політичної системи транзитивного суспільства. По-друге, політичні партії виконують роль провідного суб'єкту та агенту демократії з огляду на їх непересічну роль в електоральному процесі, особливо за умов пропорційної системи виборів. По-третє, політичні партії за визначенням мають бути самоврядними політичними організаціями, які виконують роль соціальних «ліфтів», виховуючи та просуваючи кадри професійних політиків на олімп владних структур.

3 огляду на данні останніх соціологічних досліджень, які фіксують стабільно невисокий рівень довіри та популярності українських партій та їх лідерів, а також великий рівень аномії громадян щодо партійної та політичної системи України загалом, варто наголосити, що практично усі вітчизняні партії опинилися у серйозній кризі, яка потребує якнайшвидшого розв'язання.

Отже, реальна демократизація політичного режиму сучасної України є можливою лише за умови перетворення вітчизняних партій з політтехнологічних виборчих проектів у постійно діючі ідеологічні структури представництва та захисту інтересів різних верств українського народу.

Рекомендації. На загальнонаціональних виборах у парламент та обласні ради необхідно впровадити пропорційну систему з відкритими списками з регіональними преференціями, щоб «місце під сонцем» кожного кандидата в депутати визначали не партійні лідери та керівні органи партії, а виборці - єдине джерело державної влади у демократичній системі. Така виборча система має нейтралізувати вади мажоритарної системи (домінування адміністративного ресурсу, тотальний підкуп електорату, нестійка партійна належність кандидатів у депутати) та недоліки пропорційної системи закритих списків (втрата зв'язку та елементу особистої відповідальності між виборцями та депутатами від партій, непрозоре формування виборчих списків без участі електорату, перетворення партій на корпорації комерційних інтересів, ослаблення внутрішньої партійної демократії, 
посилення ролі лідерів парламентських фракцій та одночасне знецінення «пересічного» депутатського мандата, харизматично-вождистське голосування, катастрофічне зниження професійного рівня депутатського корпусу та якості законотворчості). Привабливим є варіант пропорційної системи, який сьогодні діє в Болгарії. Як показує досвід колишніх транзитивних суспільств, які здійснили демократизацію, лише пропорційна система може забезпечити реальну лібералізацію авторитарних та напівавторитарних режимів. В Україні утвердився гібридний режим, який ще чекає справжньої демократизації.

Слід відновити 4\%-ий прохідний бар'єр. Це стимулюватиме укрупнення політичних партій через їхнє об'єднання. Політична структуризація українського суспільства прискорюватиметься, що здатне призвести врешті-решт до справжньої, а не бутафорної демократизації, коли маргінальні партії остаточно будуть усунені від великої політики. 3 іншого боку, зменшення прохідного бар'єру $35 \%$ до 4\% дозволить новим партіям втрутитися у «битву гігантів», що сприятиме оновленню партійно-політичної еліти.

Необхідно висунути більш суворі вимоги щодо чисельності політичних партій та їхньої структуризації в регіонах. Скажімо, встановити мінімальну кількість членів партії 200 тис. осіб та вимагати представництва в усіх регіонах України. Це дозволить подолати таке явище, як «диванні» партії, а також змусить ці структури працювати в усіх регіонах країни, забуваючи про вузький регіоналізм та всілякі „сепаратистські настрої”.

\section{Бібліографічний список:}

1. Білоус А.О. Політико-правові системи: світ і Україна / А.О.Білоус. - К. : Знання, 2000. - 234 с.

2. Закон України «Про політичні партії в Україні» // Відомості Верховної Ради України. - 2001. № 23. - C. 23-35.

3. Kirchheimer O. The Transformation of Western Party Systems. In Political Parties and Political Development / O.Kirchheimer - eds. J. La Polambara and M. Weiner. - Princeton, NJ: Princeton University Press. - 1966. - 175 p.

4. Кормич Л.І. Громадські об'єднання та політичні партії сучасної України / Кормич Л.І., Шелест Д.С. K. : ABPIO, 2004. - $177 \mathrm{c}$.

5. Ларсен Ст. У. Моделювання Свропи в логіці Роккана / Ст. У. Ларсен // Поліс. - 1995. - № 1. C. 34-45.

Polishchuk I. O., Modernization of the party system as a means of democratization of the political regime in Ukraine

The substantive essence and current trends of the development of the institute of political parties in Ukraine are considered. The purpose of this article is to consider the current concept of a political party and to propose mechanisms for modernizing the party system of Ukraine in order to ensure the democratization of the political regime that has been formed in our country. The author argues that political parties in their vocation a priori act as a leading subject of democratization of the political system of a transitive society. The main problem of Ukraine lies in the fact that the clan-oligarchic (nonpatrimonial) political regime and bureaucratic corporate, shadow economy do not promote the creation of capable political parties, within which there is fair and open competition, and contributes to the creation of political companies for commercial interests. Political parties of Ukraine do not fulfill their main purpose, do not provide political education of the masses and do not provide purposeful and organized character to actions of citizens to protect their own interests. The main function of Ukrainian parties is to manipulate the mass consciousness of voters during the conduct of the relevant campaigns. The weakness of Ukrainian political parties, their organizational and ideological amorphism, opens up a rather broad perspective for the teams of political technologists to bring them to the necessary "electoral condition." The main political parties represent a kind of semi-finished products for the upcoming election campaign.

For modern Ukraine, the problem of intensifying party building and crystallization of the party system of Ukraine in the direction of its depriving of the ballast of virtual and incapable structures and leaders who do not take a real part in politics is a topical issue. On the other hand, there are many party structures and brands that, if involved in the political process, have no demand for the electoral market.

Recommendations for implementation of mechanisms of modernization of the Ukrainian party system are formulated.

Key words: political party, Ukraine, modernization, democratization, political regime. 